Valóságos könyvtár - könyvtári valóság. Könyvtár- és információtudományi tanulmányok 2016. Szerk. Kiszl Péter, Boda Gáborné Köntös Nelli. Budapest, ELTE BTK Könyvtár- és Információtudományi Intézet. 2017. 89-98.

\title{
KÖNYVTÁROS ÉLETPÁLYA, TUDATOS KARRIERÉPÍTÉS
}

\author{
BARÁTNÉ HaJdu ÁGNES
}

ELTE BTK KITI, tanszékvezető egyetemi docens

\begin{abstract}
ABSZTRAKT
A közgyúitteményi és kulturális területen elsőként a Magyar Könyvtárosok Egyesülete kezdett bele egy lehetséges életpálya modell kialakításába. Az előadás időrendben végigveszi a 2014 júliusától napjainkig tartó folyamat legfontosabb lépéseit a bejelentéstől, a Magyar Könyvtárosok Egyesülete és az Informatikai és Könyvtári Szövetség közös Könyvtáros Életpályamodell Bizottság megalakulásán keresztül, az Emberi Erőforrások Minisztériuma (EMMI) szervezésében létrejött kulturális életpálya modell munkacsoportja munkájának elindulásáig. Ahhoz, hogy egy életpálya elemeit meghatározzuk, mindenképpen tisztázni kell a karrier meghatározó tényezőit, a siker szubjektív és objektív elemeit, illetve mindezek kapcsolatát az önismerettel. A sikeres életpálya nagyban függ a társadalmi és gazdasági környezetünktől, valamint az ezek által kínált lehetőségektől, melyek lehetnek motiváló, de gátló hatásúak is. Cél egy olyan kiszámítható, átlátható, igazságos, objektív és motiváló életpálya modell felvázolása, mely lehetőséget ad az érintett könyvtárosoknak a tudatos karrierépítésre. A teljesítmény a legtöbb munkakör esetében jól megragadható, jellemezhető, objektíven mérhető a könyvtárban is, azonban vannak olyan tevékenységek, amelyek csak hosszútávon ítélhetôk meg, pl. tehetséggondozás. A munkával kapcsolatos teljesítmény három kritériuma: a munkakörhöz kapcsolódó tevékenységek, a munkakörhöz köthető tulajdonságok, a munkakörhöz kapcsolódó eredmények. Az előadásnak különös aktualitást ad, hogy a Könyvtáros Életpályamodell Bizottság az ELTE Könyvtár- és Információtudományi Intézetben tartja üléseit.
\end{abstract}

\section{Preambulum}

A pedagógus előmeneteli rendszer társadalmi vitájával, majd életbelépésével az életpályamodell fogalma a közgondolkodás homlokterébe került. ${ }^{1}$ Annak ellenére, hogy az életpályát érintő elméleti és empirikus szakirodalom már régóta foglalkozik a témával, a kérdés megközelítésének kontextusa, de különösen az attitűdje a 2010-es évek kezdetétől megváltozott. Ez a folyamat egyértelmúen köthető az aktuális társadalmi és politikai folyamatokhoz. Erre reagálva a tárgykör átalakulását figyelhetjük meg a humánerőforrás-gazdálkodással foglalkozó szakemberek célkitűzései, valamint a szakmapolitikai törekvések megformálásában.

A közgyűjteményi és kulturális területen elsőként a Magyar Könyvtárosok Egyesülete (MKE) kezdett bele egy lehetséges életpályamodell kialakításába. A tanulmány időrendben végigveszi a 2014 júliusától napjainkig tartó folyamat legfontosabb lépéseit a bejelentéstől, a Magyar Könyvtárosok Egyesülete és az Informatikai és Könyvtári Szövetség (IKSZ) közös Könyvtáros Életpályamodell Bizottságának megalakulásán keresztül, 


\section{BARÁTNÉ HAJDU ÁGNES}

az EMMI szervezésében létrejött Kulturális életpályamodell munkacsoport munkájának elindulásáig. Az áttekintésnek különös jelentőséget ad, hogy a Könyvtáros életpályamodell bizottság az ELTE Könyvtár- és Információtudományi Intézetben tartja üléseit.

\section{A Könyvtáros életpályamodell bizottság megalakulása}

A pedagógus és a könyvtáros hivatás számos elemében hasonlít egymásra. Valószínúleg ennek is köszönhető, hogy hagyományosan nagy az átjárás a két pályán dolgozó szakemberek között. Ugyanakkor megfigyelhető, hogy a munkakörök, a karrier, a fizetések és számos más tényező tekintetében is folyamatos az összehasonlítgatás; az előnyök, hátrányok és kompetenciák elemzése. Természetes, hogy a preambulumban említett, a pedagógusok előmeneteli rendszerérôl szóló, nagy hatású jogszabály, mely nemcsak a karrier, hanem a követelmények, a kompetenciák, a minősítés tekintetében (csak néhány elemet kiemelve) átalakítja a tanárok hivatását, komoly változásokat indukál a további ágazatok esetében is. A helyzetet árnyalja, hogy az iskolákban dolgozó könyvtárostanárok, könyvtárostanítók mellett könyvtáros munkakörben is számosan dolgoznak - többek között olyanok, akiknek a könyvtáros diploma mellett nincs pedagógusi végzettségük - és a jogszabály szabta keretek őket kizárják a pedagógus életpályamodell hatálya alól. Így a több oldalról is jelentkező feszültség - a pedagógusok és a könyvtárosok fizetése körül megmutatkozó hatalmas szakadék, illetve az iskolai könyvtárosok körében kialakult feszültség - az MKE vezetőségét arra indította, hogy elébe menjen a folyamatoknak, sôt esetleg azokat munkájával, javaslataival serkentse és segítse. Annál is inkább, mert az életpályamodellek más területen is megjelentek, illetve elindult a kidolgozásuk, mint például a közszolgálati, a rendvédelmi, az egészségügyi stb. pályával kapcsolatban. A kérdéssel való foglalkozás szükségességét erősítette, hogy a könyvtárosok kor szerinti megoszlását megvizsgálva nyilvánvalóvá vált a középgeneráció hiánya és a nyugdíjazás felé közeledő réteg kimagasló mértéke. Ugyanakkor a könyvtárosképzésben is több olyan új elem jelentkezett, melyekkel mind a pályára való kibocsátás, mint a pályán tartás érdekében foglalkoznunk kellett. ${ }^{2}$

Az MKE 46. vándorgyưlése kis plenáris ülésén jelentette be először Bakos Klára MKE elnök a Könyvtáros Életpályamodell Bizottság életre hívását, valamint a közös gondolkodás haladéktalan elindítását. Földiák András - a Közművelődési és Közgyűjteményi Dolgozók Szakszervezete (KKDSZ) akkori elnöke - örömmel csatlakozott a gondolathoz, és az összefogás fontosságára hívta fel a figyelmet, ugyancsak a soproni vándorgyűlésen.

Mint ahogy már annyiszor, amikor az egész könyvtáros társadalmat érintő kérdések merülnek fel, a Magyar Könyvtárosok Egyesülete elnöksége mindig a Könyvtári és Informatikai Szövetséggel partnerségben kívánja azt megoldani. Így történt ez ebben az esetben is, és 2014. szeptember 17-én az MKE és az IKSZ közös Könyvtáros Életpályamodell Bizottsága megtartotta első ülését. Fontos kiemelnünk, hogy a bizottság megalakulása és a javaslat kidolgozása elsőként történt meg a közgyűjteményi és a kultu- 
KÖNYVTÁROS ÉLETPÁLYA, TUDATOS KARRIERÉPÍTÉS

rális területen! Az ELTE BTK Könyvtár- és Információtudományi Intézete felajánlotta, hogy az üléseket az intézetben tartsuk, melyet ezúton is hálásan köszönünk.

\section{A Könyvtáros Életpályamodell Bizottság összetétele}

A tagokat a két nagy könyvtáros szervezet delegálta.

- Az MKE részéről: Bartos Éva, Barátné Hajdu Ágnes, Kührner Éva, Eszenyiné Borbély Mária, Redl Károly, míg

- az IKSZ részéről: Ásványi Ilona, Benczekovits Beatrix, Fülöp Attiláné, Haszonné Kiss Katalin, Horváth Sándor Domonkos, Nagy Zsuzsanna lett tagja a bizottságnak.

A tagságban mind a könyvtártípusok, mind a szakmai kompetenciák és gyakorlatok tág köre képviselve van, azért, hogy ebben a tekintetben is a lehető legszélesebb lefedettséget és reprezentációt biztosítsunk az életpályával kapcsolatos tárgyalások során.

\section{Azéletpálya fogalma és jellemzőoi}

A könyvtáros életpályával már több esetben foglalkoztunk a múltban ${ }^{3}$, például 2001-ben, amikor a könyvtáros életpálya alakításának kérdéseit vettük számba. A 2003-2007 közötti könyvtári stratégia - többek között - a könyvtáros életpálya alakulását befolyásoló tényezőket vizsgálta, valamint az MKE a 2005. évi, Hivatása könyvtáros címmel Gödöllőn megrendezett vándorgyưlésének központi témájául is a könyvtáros hivatást választotta.

A témát érintő gondolatokat fogalmaz meg az MKE - jelenleg a szervezeteken belüli megvitatás alatt álló - 2016-2021-es időszakra vonatkozó stratégiai terve, amikor kiemeli a következőket: „Hatékony érdekérvényesítés és érdekképviselet. A szakmai érdekvédelmi tevékenység további erősítése, együttműködve más könyvtáros és civil szervezetekkel" - szükségességét.

Az életpálya alappilléreiként tekinthetünk a képzés, az elómenetel folyamatára és az illetményrendszer hármasára. Jelen tanulmányunkban elsősorban az előmenetel kérdését boncolgatjuk.

Egy-egy hivatás életpályájával kapcsolatban mindig is modellekben gondolkodtunk, amikor a bemeneti követelményeket, az előmenetelt és illetményrendszert együttesen tekintettük. Természetesen nem mindig neveztük így, de akár az illetménytábla, akár egy-egy személyes karrier mind-mind modellszerūen felfogható, sőt ábrázolható. Ahhoz, hogy hatékony és magas színvonalú, minőségi munkát várhassunk - bármely munkahelyen és munkakörben -, szükség van az érezhetô megbecsülésre és biztonságra életpályánk teljes időtartama alatt.

Az életpályamodellt gyakran összetévesztik és/vagy összemossák a teljesítményértékeléssel, mely legtöbbször valamilyen módon beépül a rendszerbe, de semmiképpen sem öncélúan és kizárólagosan. A teljesítménymérés és -értékelés ugyanakkor fontos eleme lehet egy objektív, összehasonlítható, standardizált eszközrendszernek, melyre építve struktúrát és dimenziót adhatunk a modelleknek. A Szabó Szilvia, Stréhli-Klotz Georgina szerzőpáros a közszolgálati munkával kapcsolatban írott megállapításai teljes 


\section{BARÁTNÉ HAJDU ÁGNES}

mértékben adaptálhatók a könyvtári területre: „Az új kihívások szükségszerűvé tették a korábbi, szeniorátuson alapuló közigazgatási életpálya-modell felülvizsgálatát annak érdekében, hogy a közigazgatás képes legyen megtartani az új követelményeknek jobban megfelelő szakembereket is. Magyarországon az emberi erőforrás-menedzsment - stratégiai jellegének elismertetésén túl - alapvetően ezekkel a kihívásokkal szembesül, és próbál rájuk releváns és hosszú távon is fenntartható megoldásokat kidolgozni. A gyakorlat és a kutatási eredmények egyöntetūen bizonyítják, hogy az emberi erőforrások stratégiai alapú és integrált menedz̧selése nélkül a közszolgálat egésze, de az egyes szervezetei sem képesek a velük szemben támasztott összetett elvárásokat kielégítve, eredményesen múködni."

A Könyvtáros Életpályamodell Bizottság első ülésén megfogalmazottak alapján a modellalkotás célja a kulturális ellátás színvonalának emelése, melynek alapfeltétele a bevezetőben már felvázolt hármas alappillér: a képzés, az előmenetel és a megfelelő illetményrendszer, továbbá a megbecsülés és a biztonság.

\section{Tudatos karrierépités}

Ahhoz, hogy egy életpálya elemeit meghatározzuk, mindenképpen tisztázni kell a karrier tényezőit, a siker szubjektív és objektív elemeit, illetve mindezek kapcsolatát az önismerettel, melyet azonban csak egy másik tanulmány keretében lehet kifejteni. A sikeres életpálya nagyban függ a társadalmi és gazdasági környezetünktől, valamint az ezek által kínált lehetőségektől, melyek lehetnek motiváló, de gátló hatásúak is. Cél egy olyan kiszámítható, átlátható, igazságos, objektív és motiváló életpályamodell felvázolása, mely lehetőséget ad az érintett könyvtárosoknak a tudatos karrierépítésre.

\section{A teljesitmény}

A teljesítmény a legtöbb munkakör esetében jól megragadható, jellemezhető, sőt objektíven mérhető a könyvtárban. Azonban vannak olyan tevékenységek, amelyek csak hosszú távon ítélhetôk meg, mint például a tehetséggondozás, hiszen ennek eredménye gyakran csak évek múlva látható, és esetleg nem is számszerűsíthető. Ilyen esetekben a számszerú mérés helyett az értékelést választhatjuk, pl. hozzáállás, a kompetencia stb. ${ }^{5}$ Szakács Gábor vizuálisan is megjeleníti teljesítményértékelési technikákat (1. ábra). 


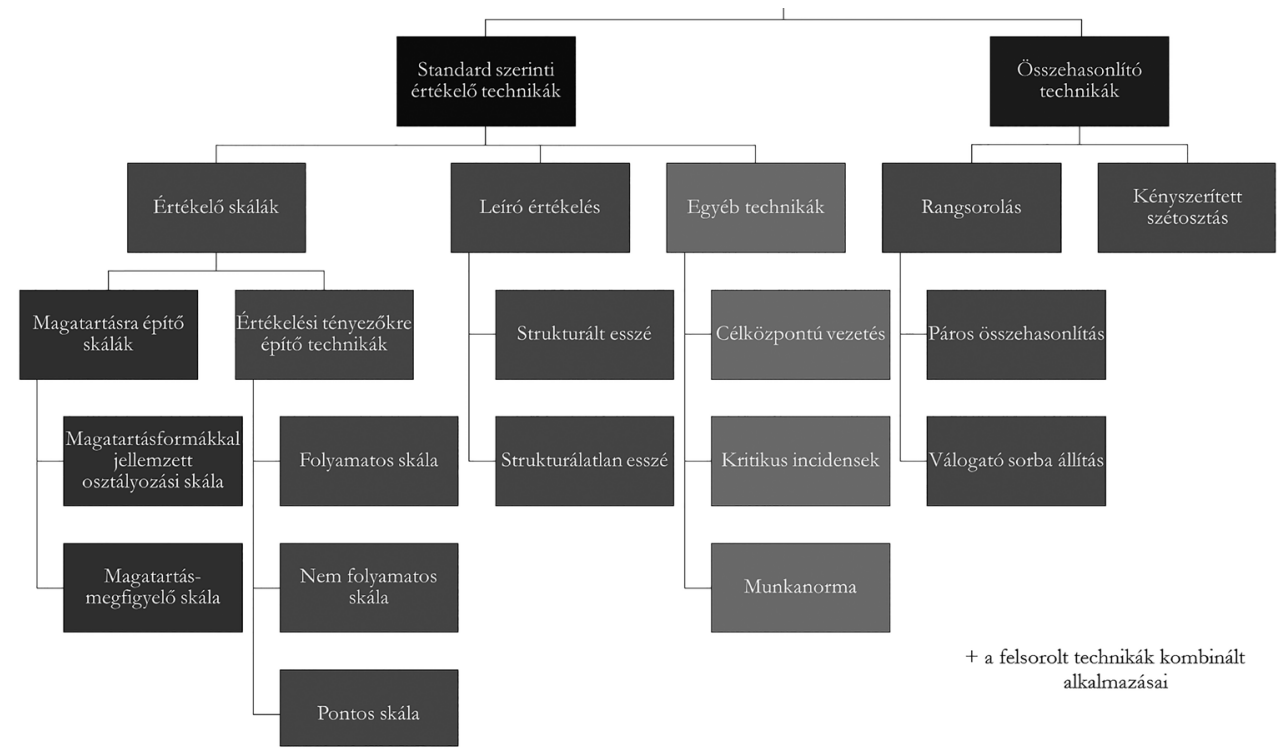

1. ábra: Teljesitményértékelési technikák

A munkával kapcsolatos teljesítmény három kritériuma (2. ábra):

- a munkakörhöz kapcsolódó tevékenységek,

- a munkakörhöz köthető tulajdonságok,

- a munkakörhöz kapcsolódó eredmények.

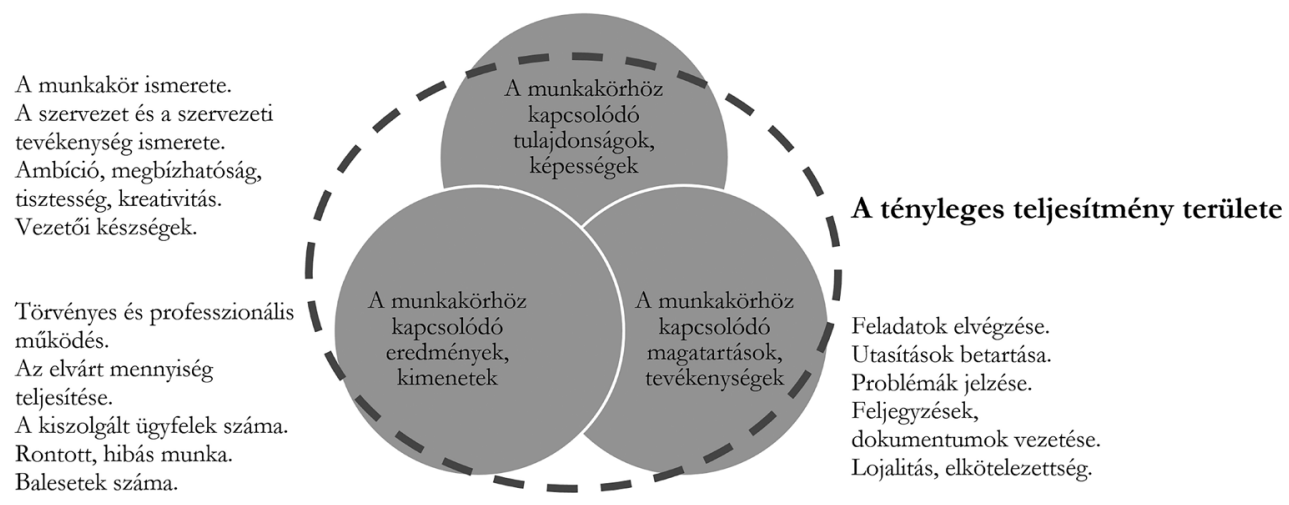

2. ábra: A teljesitmény dimenziói ${ }^{7}$

Ezekre az értékelési technikákra és dimenziókra kell építeni a könyvtáros életpályamodellben is. 


\section{BARÁTNÉ HAJDU ÁGNES}

\section{Tudatos karrierépités a diákévek alatt}

A karrierépítés speciális, és esetünkben igen lényeges területe, amikor a leendő könyvtáros, informatikus könyvtáros, könyvtárostanár a pályára kerülést megelőzően, illetve a pályakezdéssel egyidejûleg tudatosan készül a hivatására, és kezdi meg karrierjének építését, majd gondozását. Ez az időszak egy hosszú távú karrierstratégia kezdetének tekinthető.

Jellemzően korán és tudatosan kell elkezdeni. Az időpont mindenképpen legalább a végzés előtt 1-2 évvel legyen, akár BA-ról, akár MA-ról legyen szó. Ez természetesen függ a hallgató munkába állási terveitôl. A tudatosság számos területen és választásban megnyilvánulhat:

- a szabadon választható tárgyak köre,

- specializációk, minorok,

- szakdolgozati téma és témavezető,

- kutatás (egyéni, intézeti, intézeten kívüli),

- bekapcsolódás a tudományos diákköri munkába,

- publikációs lehetőség, például referátumkészítés,

- kompetenciafejlesztés, például nyelvi kompetenciák,

- $\quad[\ldots]$

A szakmai gyakorlati hely megválasztása komoly szerepet játszhat mind az ismeretek szélesítésében, mind egy speciális tudás kialakításában, de leendő munkahelyként is van realitása.

Tanulmányaik során a diákok között kialakuló kapcsolati rendszer segítheti a tervek megvalósítását, sőt gyakran évekig, ha nem életük végéig végig kíséri őket a pályájukon. Hasonló kapcsolati rendszert alakíthatnak ki a hallgatók a már pályán lévő kollégákkal, egyes munkáltatókkal, ha bekapcsolódnak az egyes szakmai szervezetek munkájába, részt vesznek például a Magyar Könyvtárosok Egyesülete rendezvényein. Évek óta jó gyakorlatként tekintenek az MKE vezetősége és a könyvtárak képviselői arra, hogy az ELTE informatikus könyvtáros hallgatói szép számban, a képzőintézmények közül messze kiemelkedő mértékben vesznek részt a vándorgyűléseken.

A tudatos karriertervezés egy nemzetközileg is elfogadott formája a hallgatói csere, az egyetemi évek alatt folytatott ERASMUS tanulmányok egy-egy külföldi egyetemen. Az ELTE Könyvtár- és Információtudományi Intézetében tanulók számára például jelenleg 19 külföldi egyetem kurzuskínálatából van lehetősége választani. ${ }^{8}$

A tudatos karrierépítés egyik fontos lépcsőfoka az álláskeresés. Pár évvel ezelőtt az álláskeresés időpontja erősen kitolódott, gyakran csak több diplomával, és tapasztalat nélkül, a húszas éveik végén kezdtek ismerkedni a munkaerőpiaccal az egyetemisták. Ma számos okból eredően ez az idő lényegesen előrébb került, gyakran már egyetem alatt, különösen a felsőbb évfolyamok esetén teljesen általános, hogy a hallgatók munkát vállalnak. Ez a munka nem feltétlenül kötődik a könyvtárhoz, főként az alsóbb évfolyamokon, de a gyakorlati tapasztalat, a munkahelyi szocializációs élmények és hatások, a csapatban folytatott munka komoly előnyt jelent a későbbi alkalmazásukkor is. Annak ellenére, hogy ma már előfordul, hogy a végzős MA-s diákok több lehetőség közül vá- 
laszthatnak, mégis érzékelhető, hogy a verseny erősödik, és az egyetemen elsajátítható átlagos tudáson felül érdemes egyéni felelősséggel közelíteni a kompetenciák fejlesztéséhez. Ezt erősítik a felsőoktatási intézményeknek azon törekvései, hogy a képesítési követelményeket folyamatosan aktualizálják, hogy piacképes ismeretekkel és kompetenciákkal vértezzék fel diákjaikat.

A sikeres álláskeresésnek számos eleme van. Az előzőekben az önmagunk felkészítéséról volt szó, de természetesen ennek a folyamatnak nem szabad megtorpannia, lényeges az információgyűjtés és a választott munkakörhöz való kötődés kialakítása, valamint demonstrálása. Akár már pályakezdőként lehet foglalkozni egy énmárka kiépítésével, de erre később mindenképpen sort kell keríteni. Ugyanakkor keresni kell a lehetőséget, és bizonyítani már az álláskeresés, a jelentkezés alkalmával, hogy az illető tisztában van az új, innovatív technikák használatával, és elkötelezett az adott intézmény, munkakör vonatkozásában.

\section{A Könyvtáros Életpályamodell Bizottság müködése és határozatai}

A bizottságnak kiindulópontként néhány alapadatra volt szüksége, hogy felmérje az érintettek körét, a jelenlegi helyzetet, a várható folyamatokat és hatásokat. Ilyen adat volt például a közalkalmazott könyvtárosok száma - az iskolai könyvtárosok kivételével 2013-ban:

- 10048 fő a könyvtárban dolgozók száma,

- 8500 fő a könyvtáros munkakörben foglalkoztatottak száma.

Az indulás első szakaszában a bizottság már hozott néhány elvi határozatot:

- Az évek óta várt bérfejlesztés egy kiszámitható, átlátható, igazságos, objektiv és motiváló életpálya elemeként jelenjen meg minél elöbb!

- A kulturális terület együttes megvalósításának van realitása.

- Beindítása egyszerre történjen valamennyi érintett esetében, tekintettel a pályán elért eddigi eredményekre, pozíciókra.

- A könyvtári terület sajátosságait elsősorban maga a szakma tudja meghatározni.

- Mintaként tekintsünk a már elfogadott pedagógus életpályamodellre, vegyük át annak szerkezetét és szorzóit is.

- A modellt kapcsoljuk össze a feladatrendszer definiálásával, a kihívásokra adandó válaszainkkal.

- A kidolgozott illetményrendszer ösztönözze és ismerje el a magasabb végzettséget és a minőségi munkát.

- A szorzók minden kategóriában legyenek ugyanazok.

- A szorzók különböző szintrôl indulnak a BA és az MA végzettség esetén, ezért két táblát dolgozzunk ki.

- Az életpályamodell a könyvtárban dolgozók teljes körét érintse.

- Az ismert bértábla rendszerén, kategóriáin változtatást javaslunk. Az A és az I, valamint J kategóriákat megszüntetnénk. (Ennek ellenére kidolgoztuk az ezekre 


\section{BARÁTNÉ HAJDU ÁGNES}

vonatkozó bértáblát is, de az életpályamodell bevezetése esetén ezek szerepüket veszítenék.)

- Az első fizetési fokozat a mindenkori minimálbér, illetve a diplomás minimálbér függvénye, illetve annak meghatározott százaléka legyen.

Az első pillanatban világos volt, hogy az életpályamodell kiépítése során szükség van egy szakaszolásra, mellyel kapcsolatban az a cél, hogy egy folyamatosan építkező, fejlődést mutató, a karrierépítés és karriergondozás jellemzőit is magában foglaló rendszer épüljön ki. Az egyes szakaszokhoz kapcsolódóan - azokat megelőzően - minősítő eljárásokat célszerű beépíteni. A teljesítmény elismerése legyen közvetlen kapcsolatban az előmenetellel, ugyanakkor a rendszerben szükség van mind az erkölcsi, mind az anyagi elismerés egymást kiegészítő és erősítő beépítésére.

Kívánalmak:

- Az elvárt teljesítmény és a követelmények, illetve a kialakított mutatók szervesen kapcsolódjanak a szervezet stratégiai céljaihoz.

- Felkészült értékelők, folyamatos visszajelzések, fejlesztést/fejlődést szolgáló támogatás, tanácsadás szükséges.

- A teljesítményértékelő rendszer folyamatos vizsgálata, fejlesztése elengedhetetlen.

- A minősítési rendszer hatással lesz/van a humánerőforrás-gazdálkodás számos elemére, mint például a kiválasztás, a beilleszkedés megtervezésére, a karriertervezés, az utánpótlásnevelés, a szervezetfejlesztés, a tehetséggondozás stb. folyamatára.

- A tervezett modell tartalma legyen alkalmas a teljes életpálya átfogására, ugyanakkor a kisebb gyakorlattal rendelkezők minősítésének kellően árnyalt leírására is.

- A minősítő eljárások során nagyobb mértékű legyen a kitöltős és automatikusan kreditálható rész (objektív), mint a szakértői értékelés (esetlegesen szubjektív).

- A képesítési követelmények jelentsenek kiinduló pontot az értékelésnél (kompetenciák és indikátorok rendszere).

- A munkáltatói és a szakértôi vélemény, illetve önértékelés együttese jelenjen meg az egyes szakaszoknál.

- Lehetséges legyen a képzések, továbbképzések súlyozott és differenciált megítélése.

A bizottság a könyvtáros életpályamodellben öt szakasz megkülönböztetését javasolta:

- Gyakornok

- Könyvtáros I.

- Könyvtáros II.

- Főkönyvtáros

- Mesterkönyvtáros. 
Előnyök:

- Az egységes szorzórendszer, mely már önmagában is nagyobb előmenetelt tesz lehetővé.

- A magasabb szorzók miatt a fizetés emelkedése lényegesen jelentősebb.

- Az előmenetel a minősítő eljárások beépítésével nem automatikus, hanem a teljesítményhez kötődik.

- Javaslatunk egyértelmúen támogatja az iskolázottságot és érezhetô a folyamatos bérnövekedés.

A bizottság munkájának bemutatása érdekében számos konferencián ismertettük a javaslatainkat. Az első országos rendezvényre, 2014. november 16-ára, meghívtuk a minisztérium képviselőit, a kulturális társszervezeteket, valamint a KKDSZ szakembereit, hogy ezzel is segítsük a párbeszéd elindulását és a javaslataink megismerését.

\section{A Kulturális életpályamodell}

Hoppál Péter kultúráért felelős államtitkár a kulturális életpályamodell kidolgozásának elindítását 2015. április 1-jén jelentette be a Kulturális Ágazati Érdekegyeztető Tanácsban. A Kulturális életpályamodell munkacsoport 2015. június 11-én megtartott első ülésén meghatároztuk azokat a lépéseket és alapfeltételeket, valamint a kötelező elemeket, melyek szükségesek egy közös modell kidolgozásához:

- Képesítési követelmények átgondolása.

- A 150/1992. (XI. 20.) Korm. rendelet - a közalkalmazottak jogállásáról - módosítása.

- A gyakornoki rendszer bevezetése.

- Továbbképzés - nem egyforma intenzitású az érintett területeken.

- Minősítési rendszer kidolgozása.

- Bérfejlesztés.

A folyamatok elindultak. A Magyar Könyvtárosok Egyesülete - a többi szakmai szervezettel együttmúködve - stratégiai feladatának tekinti az egyeztetések folytatását és a könyvtárosok erkölcsi, anyagi elismerési rendszerének kialakítását, melynek lényeges eleme a tudatos karrierépítés és -gondozás.

\section{Irodalom és jegyzetek}

${ }^{1}$ 326/2013. (VIII. 30.) Korm. rendelet a pedagógusok előmeneteli rendszeréről és a közalkalmazottak jogállásáról szóló 1992. évi XXXIII. törvény köznevelési intézményekben történő végrehajtásáról. Forrás: http://net.jogtar.hu/jr/gen/hjegy_doc.cgi?docid=A1300326.KOR [2016. január 19.]

${ }^{2}$ KISZL Péter: Újratervezés a könyvtárosképzésben. = Tudományos és Múszaki Tájékoztatás, 62. évf. 11-12. sz. 2015. 399-414. p. 


\section{BARÁTNÉ HAJDU ÁGNES}

${ }^{3}$ BARÁTNÉ HAJDU Ágnes: Szakmai beszámoló a kiszámítható életpálya c. konferenciáról. Forrás: http://mke.info.hu/wp-content/uploads/2013/09/Szakmai_beszamolo_A_kisza[-] mithato_eletpalya_kepekkel.pdf [2016. január 19.]

${ }^{4}$ SZABÓ Szilvia - STRÉHLI-KLOTZ Georgina: Közszolgálati életpályák: emberi erőforrás áramlás. ÁROP - 2.2.21 Tudásalapú közszolgálati előmenetel. Budapest, Nemzeti Közszolgálati Egyetem, 2014. 7. p.

${ }^{5}$ Forrás: NEMESKÉRI Gyula - PATAKI Csilla: A HR gyakorlata. Budapest, Ergofit Kft., 2007. 225-234. p.

${ }^{6}$ SZAKÁCS Gábor: Közszolgálati teljesítménymenedzsment: a teljesítménymenedzsment humánfolyamata. ÁROP - 2.2.21 Tudásalapú közszolgálati előmenetel. Budapest, Nemzeti Közszolgálati Egyetem, 2014. 39. p.

${ }^{7}$ SZAKÁCS Gábor: Közszolgálati teljesítménymenedzsment. A teljesítménymenedzsment humánfolyamata. ÁROP - 2.2.21 Tudásalapú közszolgálati előmenetel. Budapest, Nemzeti Közszolgálati Egyetem, 2014. 30. p. Forrás: NORBERT F. Elbert - KAROLINY Mártonné - FARKAS Ferenc - POÓR József: Személyzeti/emberi erőforrás menedzsment kézikönyv. Budapest, KJK KERSZÖV Jogi és Üzleti Kiadó Kft., 2001. 260. p.; GYÖKÉR Irén - FINNA Hennrietta - KRAJCSÁK Zoltán: Emberi erőforrás menedzsment. Budapest, Budapesti Múszaki és Gazdaságtudományi Egyetem, 2010. 144. p.

${ }^{8}$ ELTE Könyvtár- és Információtudományi Intézet honlapja az ERASMUS kapcsolatokról. Forrás: http://lis.elte.hu/OKTATAS/index.html [2016. január 19.]

Barátné Hajdu Ágnes az ELTE BTK Könyvtár- és Információtudományi Intézet Könyvtártudományi Tanszékének vezetője. A Magyar Könyvtárosok Egyesületének elnöke; az ETO szerkesztőbizottságának, az ISKO Tudományos Tanácsadó Testületének és az IFLA vezetőtestületének tagja. Fő kutatási területei közé tartoznak az ismeretszervezés episztemológiai kérdései és az információ megjelenítése. 